\title{
Feminist Mothering: Challenging Gender Inequality by Resisting the Institution of Motherhood and Raising Children to be Critical Agents of Social Change*
}

\author{
Fiona Joy Green University of Winnipeg
}

\begin{abstract}
Résumé
Malgré l'importante contribution des féministes à la recherche et à la théorie féministes dans le domaine de la maternité et de l'éducation des enfants par les femmes, rares sont les chercheurs s'attachant à analyser l'éducation féministe des enfants comme source de force, comme lieu de résistance potentiel à la patriarchie et d'activisme révolutionnaire. Le présent article explore la façon dont le travail de mères délibérément féministes peut donner aux femmes le pouvoir d'échapper au carcan de la maternité patriarcale, de créer leurs propres modèles d'éducation des enfants et d'en faire ainsi des citoyens actifs susceptibles de défendre la justice sociale. Des extraits de plusieurs entrevues réalisées avec seize mères se définissant comme féministes, entrevues menées dans le cadre d'un projet de plus grande envergure sur l'éducation féministe des enfants, donnent des exemples concrets sur la façon dont une conscience féministe peut transformer le travail de mère et en faire, d'une part, ce que Ruddick envisageait comme une expression enrichissante et disciplinée d'une conscience, d'autre part, le locus du changement social délibéré prôné par Chodorow (1978) et Rich (1986).
\end{abstract}

\begin{abstract}
In spite of the significant contributions of feminists to feminist theorizing and research on motherhood and mothering, only a few scholars are paying attention to the analysis of the potential of feminist mothering as a site of women's strength and resistance to patriarchy and as a location of revolutionary activism. This article explores how the work of conscious feminist mothers can empower women to break free from the rules of patriarchal motherhood to create their own models of mothering and, in turn, practice the invaluable work of rearing children to be active conscientious citizens for social justice. Excerpts from several interviews with sixteen self-identified feminist mothers, conducted for a larger research project on feminist mothering, provide concrete examples of how having a feminist consciousness transform the work of mothering into both a "rewarding, disciplined expression of conscience" proposed by Ruddick, and a location of active social change theorized by Chodorow (1978) and Rich (1986)
\end{abstract}

*I would like to thank the anonymous reviewers and the Editorial Board of Socialist Studies for providing critical commentary on this article. 


\section{Introduction}

As I have said, the work of mothering can become a rewarding, disciplined expression of conscience. In order for this opportunity to be realized, either collectively or by individual mothers, maternal thought will have to be transformed by feminist consciousness (Ruddick, 1984:223).

To destroy the institution [of motherhood] is not to abolish motherhood. It is to release the creation and sustenance of life into the same realm of decision, struggle, surprise, imagination and conscious intelligence, as any other difficult, but freely chosen work (Rich, 1986:280).

In her classic book Of Woman Born: Motherhood as Experience and Institution, poet, feminist and mother, Adrienne Rich argues that motherhood has two meanings in which "one is superimposed on the other: the potential relationship of any woman to her powers of reproduction and to children; and the institution, which aims at ensuring that that potential - and all women - shall remain under male control" (emphasis in original. Rich, 1986:13). Once women understand that it is the social construction of women's reproductive power and the configuration of their relationships with their family members that are burdensome and overbearing and not mothering itself, then, Rich states, they can challenge and transform the oppressive conditions of motherhood through their power as mothers. Through claiming the knowledge of their own experiences, mothers are aware of the dual meaning of motherhood, conscious of alternatives and resistance, and cognisant of their ability to confront and transgress unacceptable dominating values of patriarchal constructions of motherhood and mothering practices.

Philosopher, feminist and mother, Sara Ruddick posits that the work of mothering - the actual caring practice one engages in to ensure the preservation, personal growth and social acceptability of a child - can be transformed by feminist consciousness and caring labour. She notes that the work of mothering, when informed by feminist consciousness, "shifts the balance away from illusion and passivity toward active responsibility and engagement", thus affirming "its own criteria of acceptability" (1984:222). Accordingly, mothers with a feminist conscious move from an inauthentic obedience to the values of the dominant culture toward appreciating how many of these dominant values are unacceptable and, thus, can be actively challenged (1989:238).

Interdisciplinary scholar, feminist and mother, Nancy Chodorow (1978), argues in The Reproduction of Mothering, that the work of mothering is integral to society. Mothers socialize children in many areas, including: social values, mores and morality; relations between the sexes; ideology about women and men; and the "sexual division of labor 
and sexual inequality both inside and outside the family and the non-familial world" (1978:3). Implicit in Chodorow's analysis is an understanding that mothering is central to social change. And because "women's mothering is of profound importance to the family," it is also central to transforming larger social structures and society (1978:3).

While the institution of motherhood has been criticised by feminists, research into the meaning and practice of feminist mothering has been limited and is just now beginning to develop. In the early 1980s, for instance, psychiatrist and feminist, Ann Dally, noted the lack of early feminist literature addressing the mother work involved in raising children and its avoidance of facing "the deeper problems of motherhood" (1982:174). The 1990s began with the publication of Feminist Mothers (Gordon, 1994) and was shortly followed in 1994 by Mother Journeys: Feminist Write About Mothering (Reddy, Roth \& Sheldon, 1994). Both books begin to explore what mothering has meant to women who identify themselves as feminist and conclude, echoing Rich, that the social construction of motherhood is a narrow and limiting ideal that does not encapsulate the complexity of the experiences of women who have children.

In the concluding chapter of Feminist Mothers, Tuula Gordon (1994) begins to develop a definition of a feminist mother. Here she notes that if she were able to single out any particular factors to define feminist mothers from her study of fifty-two employed mothers living in England and Finland, they would be:

\begin{abstract}
The way in which they challenge and criticize myths of motherhood; the way in which they consider it their right to work (in the labour force); the antisexist way in which they bring up their children; the way in which they expect fathers of their children to participate in joint everyday lives; and the way in which many of them are politically active (Gordon, 1990:149).
\end{abstract}

Editors Maureen Reddy, Martha Roth and Amy Sheldon define a feminist mother in the prologue of Mother Journeys as "the mother who criticizes the status quo and who does not want to turn her children into little patriarchal replicants." (1994:2).

The late 1990 s and the first half decade of the 21 st century has witnessed a growing interest in feminism and motherhood, with the formation of the Toronto-based Association for Research on Mothering (ARM) in 1998 after a conference on mothers and daughters. ARM has continued to host bi-annual conferences, as well as publish a bi-annual journal that focuses on feminism, motherhood and mothering in various disciplines and genres. Recent publications, such as The Cultural Contradictions of Motherhood (Hayes, 1996), The Mommy Myth (Douglas \& Michaels, 2004) and Maternal Desire: On Children, Love and Inner Life (de Marneffe, 2004) are critical of 


\begin{abstract}
"intensive mothering" and the "new momism" associated with contemporary motherhood for setting women up to feel guilty and to fail. Lastly, the most recent literary genre of 'momoirs', dedicated to sharing the often-untold and brutally honest lived experiences of new mothers, reveals the conflict and challenges of meeting the expectations of modern motherhood.
\end{abstract}

In addition to these currently popular contributions to the discourse on mothering, a growing number of scholars are paying attention to the analysis of the potential of feminist mothering as a site of women's strength and resistance to patriarchy and as a location of revolutionary activism. Feminist, mother, and Director of the Association for Research on Mothering, Dr. Andrea O'Reilly speaks of feminist mothering in these terms:

\begin{abstract}
While we may not yet know completely what empowered [or feminist] mothering looks like, we, in interrupting and deconstructing the patriarchal narrative of motherhood, destabilize the hold this discourse has on the meaning and practice of mothering, and clear a space for the articulation of counter narratives of mothering (O'Reilly, 2004:12).
\end{abstract}

Investigating the work of feminist mothering is a crucial area of research because it further develops the theorizing of feminist mothering originally posited by Rich in 1976 (close to three decades ago) that advocates the use of feminist consciousness in the endeavour of destroying the institution of motherhood, and by Ruddick (1984) who saw the necessity of feminist consciousness in order to create a rewarding and disciplined expression of conscience through mothering. Exploring the meaning and practice of feminist mothering is also necessary because of the considerable need to both acknowledge and learn from the invaluable work that feminist mothers are doing as they challenge the institution of motherhood and engage in the caring labour of guiding children to be conscientious citizens. In doing so, we may enrich our understanding of how some self-identified feminist mothers define feminist mothering, and how and why it is a site of resistance to patriarchy and a place of social activism that can potentially transform families and society.

This article contributes to the growing research in feminist scholarship by exploring how the work of being a conscious feminist mother, proposed by Gordon (1994), O'Reilly (2004), Reddy et. al. (1994), Rich (1986) and Ruddick (1984) can empower women to break free from the rules of patriarchal motherhood and create their own models of mothering. Not only does it expand upon these two actions associated with feminist mothering, it also contributes to the research on feminist mothering by providing concrete examples of how a number of self-identified feminist mothers living within a 
particular geographical location during a specific historical time period create a working model of feminist mothering for themselves, where they consciously intertwine their feminism and mothering, making it a site of resistance to patriarchal constructions of motherhood and parenting. As "outlaws from the institution of motherhood" (Rich, 1986:195), these particular mothers demonstrate how feminism is the vehicle of empowerment and mothering is the site of transformation for themselves and for their children. These feminist mothers provide concrete examples of how a feminist consciousness can transform the work of mothering into both a "rewarding, disciplined expression of conscience" proposed by Ruddick (1984), and a location for active social change theorized by Chodorow (1978) and Rich (1986).

\section{Feminist Mothers}

As agents who consciously engage feminism in the everyday realties of their mothering, these particular feminist mothers consider mothering to be a site of resistance to the institution of motherhood and believe that sustained practices of their feminist mothering yield possibilities for greater social change. A necessary step to knowing and doing this work is to be critical of and understand the damaging effects of patriarchal standards of motherhood for women and children. Through critiquing the regulation and harm inflicted on women and children within motherhood, these feminist mothers reframe mothering for themselves, and develop alternative ways to mother by refusing to acquiesce to the oppressive elements within conventional motherhood.

All of the women I spoke with understand motherhood to be untenable and, to a large degree, oppressive to women and children. While the institution of motherhood is invisible, in the sense that it cannot be seen or touched because, as Rich (1986: 274-75) notes, there is "no symbolic architecture, no visible embodiment of authority, power, or of potential or actual violence," these women nevertheless feel the real and harmful stresses of motherhood. Two of the most significant elements of motherhood they identify are the debilitating patriarchal/ nuclear family structure and the damaging and disabling stereotype of the "good" mother.

\section{Understanding Motherhood and the 'Ideal Mother'}

To highlight these insights, I draw on an interview with Laura, a thirty-eight year old, Euro-Canadian married mother of two children under the age of two years. At the time of our interview Laura was on maternity leave from her position as a university professor, having just given birth to her second daughter three months earlier. Like the other interviewees, Laura acknowledges the overwhelming presence of the stereotypical mother and the many negative characteristics and expectations of motherhood that are associated 
with it. When I asked her about her concept of the "ideal mother," Laura tells me:

Oh, mothers are, according to the image, nurturing, and they stay home if they're 'good' mothers. Of course, then we can nail them for not making money and being 'welfare moms', unless they have rich husbands. It 's O.K. to stay home if you have a rich husband... It's combined with the stereotype of housewife and that's one of the problems.

So they have dinner on the table for their husbands when they come home at 5:30. They sometimes nag their children, but they're supposed to. It's kind of a good thing-bad thing. They clean up after everybody. They do all the house cleaning.

They're sweet. They're volunteers. They go out and drive children around wherever all the children need to be driven. They sit on the PTA. They're active only in family things. They're NOT politically active. They DON'T go to Take Back the Night Marches, but they'll be involved in things that affect their children.

And their only goal, actually, is to protect and take care of and keep a nice, happy, safe home. They don't curse. They don't have sex. How they have kids, I don't know, 'cause they don't have sex. (Laughter). They don't do anything for themselves. Everything they do is for their kids and husbands.

Laura understands, as do the other feminist mothers I spoke with, that the 'ideal' mother is a middle-class, heterosexual married woman who takes on the qualities associated with the stereotypical wife. Laura's analysis that perfect mothers are not politically active demonstrates an understanding that the family is to come first and that all other activities are to be disregarded because they draw women away from their child-rearing and familial responsibilities. Laura also recognizes the power imbalance within the patriarchal family structure. She sees, for example, how treating the needs and wants of other family members as more important than those of mothers creates and enforces power relationships within the family that are skewed in favour of men and disadvantage women and children. She agrees with Rich (1986: 42), who notes that:

Institutional motherhood demands of women maternal 'instinct' rather than intelligence, selflessness rather than self-realization, relation to others rather than creation of self. Motherhood is 'sacred' as long as its offspring are 'legitimate' - that is, as long as the child bears the name of the father who legally controls the mother. 
Laura thinks that this power discrepancy not only puts men in a position of authority over women and children, it also puts women in a subordinate position to the desires and wants of their husbands and, to a lesser extent, to those of their children. While Laura notes that the nurturing and caring aspects of the stereotype are positive, she is nevertheless critical of the harmful aspects of motherhood and the ideal mother:

\begin{abstract}
Real people should take care of themselves. Nobody should value themselves so little that they come behind everybody, including their kids, including their spouse. Real people shouldn't limit their options in the world so much, so profoundly. Yes, you limit your options to some extent. That's just practical, but not so thoroughly as the stereotype.
\end{abstract}

It 's harmful to them, and it 's harmful to the kids, whether they're boys or girls. It teaches girls to be stunted human beings, if you actually live that way. And it teaches boys to expect stunted human beings, and expect a slave.

The self-abnegation is awful, and not being out in the world, to me, is not being a full person. And I don't mean necessarily working for money. I just mean being a presence in the world, being active and doing things. And you can't when your life is one hundred percent involved around your home.

It's bad for the woman. It's bad for the husband! I don't think having a slave is good for people. I think power corrupts and the more you feel that you have somebody at your beck and call, the more corrupting it is. So, I think it's bad for everybody.

For Laura, the expectations placed on mothers and on children are limiting and damaging. She uses the language of enslavement, victimization and abuse to describe the negative implications of motherhood for mothers, children and husbands. She also recognizes that she has the ability to mother differently from the stereotypical standard of mothering she so easily describes when she says, "To mother the way like Betty Crocker, would be awful for my daughters and it would be awful for me. It wouldn't be true to me."

\title{
Re-Framing Mothering
}

All of the women I interviewed note how the expectations placed on mothers and on children are restraining and damaging, with many identifying Betty Crocker as the icon of the stereotypical 'good' mother who perfectly embodies motherhood. The fabricated image and values of Betty Crocker are also ideals they work against internalising. 
When Andrea moved back to Winnipeg from Toronto, and was unable to find a job or to finish her MA thesis, she quickly moved from identifying herself as a full-time employee and graduate student to seeing herself as a stay-at-home mom. At aged thirtyone, married and mother of a two-year-old daughter, Andrea went from contributing financially to the household to being dependent upon her husband, whose home-based business supports the family. The most difficult aspect of this change for Andrea was understanding and dealing with the tension between what she knew about mothering and what she had grown up hearing and seeing about motherhood. She describes the process of this work:

I had to struggle within myself between what I know intellectually and what I feel I'm supposed to do. Because I really feel there is incredible pressure and we'd be hard-pressed to put our finger on who it's coming from, but I think it's out there.

And specifically, at this point in my life, I am, for all intents and purposes, a stay-at-home mom with a very part-time job. And where my identity fits into that is really a big struggle for me.

I'm struggling with my identity as someone who makes no financial contribution to my household and who I am as an individual compared to the Betty Crocker stay-at-home mom stereotype. As I said, between what I know intellectually and my ability to reject the image of what a stay-at-home mom is, and wanting, on some level, to embrace certain aspects of that and wanting on others to reject other aspects wholeheartedly.

Through analysing and resisting the internalisation of the social definition of stay-athome mothers, Andrea establishes a way of mothering that is suitable for herself. She mothers her daughter in ways that coincide with her ethos and vision of mothering rather than with that of society's. Through the process of several intense conversations with a close friend who was visiting from Toronto, Andrea was able to make sense of the tension she was experiencing between the socially expected role of wife and her own vision of mothering:

I hadn't recognized that what society talks about when they talk about mother is also what they talk about with wife. That for the rest of the world, those two things are intertwined and, that, if you are a mother, you SHOULD be a wife. First and very importantly you must be married. And that you would also, as part of your mothering duties, do things like the laundry and the cleaning and the cooking and whatever else to take care of the home. 


\begin{abstract}
That wasn't what mothering was about for me. And it took my friend pointing this out for me to understand that, in fact, my perception of mothering was really different than what the world's concept is, what society's concept is.

I've made peace with the concept of being a stay-at-home mom. For me, it was very much an intellectuallemotional issue, that I had to be able to say that "I choose this, and that it's OK. And, that I can make it be whatever I want it to be. But it doesn't have to be what anyone else says it's gonna be."
\end{abstract}

By simultaneously rejecting the role of wife and embracing the role of mother, Andrea renounces the interconnectedness of the roles of wife and mother and creates a practice of mothering for herself. Staying home with her daughter is right for Andrea because she has been able to become a mother in a way that is true to her own vision of mothering. By not complying with the expectation that mothers solely take on the duties and responsibilities associated with the role of wife, Andrea distances herself from the role of wife and embraces her relationship with her daughter. She stays grounded in her own experience and remains critical of the pressures to conform to an ideal of mothering that causes discomfort and stress. Andrea has re-shaped mothering for herself, as she says, in a way that makes her feel "happy while doing it."

When defined on their own terms, mothering is a dynamic place for creativity where women can become more themselves. Based on their own knowledge and experience, they uncover the restrictive and damaging aspects of motherhood and the negative repercussions of these for women and children and, to a lesser extent, for men. In their critical response to the institution, they break the rules of motherhood and create distance from it. In the process, they re-shape and re-define mothering for themselves and, thus, practice self-governance.

\title{
Consciously Mothering
}

Feminist mothers not only do the intellectual and practical work of identifying and resisting the damaging components of the motherhood, they sculpt space within their mothering where they can develop relationships with their children that differs from socially prescribed models of motherhood. Each of the women I spoke with believes her mothering to be a feminist act. Inherent then, in this political act, is challenging the expectations placed upon them as mothers to teach their children about injustices and various forms of oppression.

May, aged forty, illustrates how feminist mothers recognize the influence they have in the lives of their children and the responsibility they have as mothers to the next 
generation. As a recently separated mother of two teenaged daughters, May maintains:

\begin{abstract}
Being feminists, we are trying to change society, and being a mother is one of the effective ways we can change society. We can change the new generation. We can help them to think critically on different issues by presenting them with all these ideas.
\end{abstract}

Like the other feminist mothers, May spends time with her daughters talking about what they read in newspapers, magazines and books (associated with school and otherwise), and what they see in films and on TV, often making what she calls "direct and informal comments on why things are happening." Other feminist mothers recognize the importance and significance of reading to their children when they are young and discussing what they were reading. They make sure they choose material, whether videos, books, magazines or toys, that provide various examples of gender, race and sexuality, and speak with their children about the instances of stereotyping, marginalisation and negative depictions of people when they appear. Francis, for instance, the forty-five-year-old lone mother of a nine-year-old son, reads to and encourages her son to read stories in various ways. When he was young, they would replace the pronouns of the characters, sometimes making all of the characters the same gender or, at others, mixing the gender of the characters. In doing so, they created space to discuss assumptions made about people based on their gender identity and, to a lesser extent, their class and ethnicity.

Over the years, some of these women have encouraged their children to participate in various programs. May, for example, enrolled her daughters in workshops within Winnipeg's Black community that specifically address racism and sexism, and in seminars and theatre groups that address ways to effectively understand and resist various forms of oppression. Because keeping communication open with her children is basic to her feminist mothering, May discusses the work they do in these meetings and how they feel and think about what they are exposed to:

I am consciously thinking about it all the time, 'cause I have two lives in my hand and I try to do the best I can to make them understand how the world is. Having kids around and raising kids means always having the thought in the back of my mind, "What am I trying to pass on to these kids?"

\title{
Loving Labour: Detachment and Honouring Autonomous Children
}

These women are aware that they can easily overpower their children as adults and mothers, and that they must be vigilant to ensure that they make space for their children to develop 
and become who they want to be without being coerced by their mothers and others. Ruddick (1989: 131) notes that a defining aspect of caring labour associated with the work of mothering is "to maintain mutually helpful connections with another person-or animal-whose separateness they create and respect. Hence, they are continuously involved with issues of connection, separation, development, change and the limits of control" (1989: 131).

Ruddick (1984: 216) alerts us to the temptation of "excessive control" that can emerge in the work of mothering, particularly in a mother's interest in preserving the life of her child and fostering the child's growth. Reflective mothers, she notes (1984: 217), are able to identify rigid or excessive control as they develop an attitude of "keeping over acquiring, of conserving the fragile, of maintaining whatever is at hand and necessary to the child's life." Moreover, "holding, preserving mothers have distinctive ways of seeing and being in the world that are worth considering" (Ruddick, 1984: 217).

Being connected with children in a way that is not controlling but, rather, respectful and loving, is central to the mothering work of feminist mothers. May told me that she still has to watch the instances in which she tends to behave in a domineering kind of way, noting that:

It's a big challenge sometimes, because it's not easy to translate what you believe in when it comes to your own kids. Sometimes there's a little bit of a contradiction there, and they pick it up very easily and tell you. Then you gotta go back and sift through it again, and say, "Well, how could I do this differently?"

Like the other feminist mothers, May engages in this reflective work of mothering because she sees her children as subjective beings, as people in their own right who are entitled to making and being held accountable for their own decisions.

Central to the work of acknowledging children as separate beings is what psychiatrist, feminist and author Ann Dally (1982: 205) calls, "mature conceptual thinking." That is, "having the ability to regard other people as separate and with their own needs, and the ability to foresee the likely consequences of certain events or actions" (Dally, 1982: 205). In response to the ever changing development of their growing children, Ruddick reasons that mothers must be simultaneously flexible and changing, and practice a humility that "accepts not only the facts of damage and death, but also the facts of the independent and uncontrollable, developing and increasingly separate existences of the lives (they seek) to preserve" (1984:217). Accordingly: 


\begin{abstract}
The love of children is not only the most intense of attachments, but it is also a detachment, a giving up, a letting grow. To love a child without seizing or using it, to see the child's reality with the patient, loving eye of attention such loving and attending might well describe the separation of mother and child from the mother's point of view. (Ruddick, 1984:224)
\end{abstract}

Loving detachment, notes Dally (1982:205) also "requires special talents, such as perception, concentration and the capacity to endure anxiety and suffering."

The women I spoke with consciously practice the act of separating themselves from their children through loving detachment. And while they acknowledge that this is difficult work, they choose to mother in this way because, as feminists, they value autonomy for all human beings.

In the work of ensuring their children's personal growth and social acceptability, these feminist mothers consciously provide their children with the tools necessary to be autonomous, which include being critical thinkers and active social citizens.

Shar, a fifty-year-old, retired teacher and a single mother of three adult children and a recent grandmother of a newborn, provides one example of how this can be done. In her work as a mother and in caring for young children in her small, home-based child-care, Shar values people's autonomy and ability to think for themselves. Shar tells me that as a young mother she quickly realized that the more she responded to and trusted her children's sense of what they needed rather than overpowering them with what she thought they needed, they experienced less frustration and aggression.

In practical terms this meant taking her youngest daughter out of school and teaching her at home because of problems her daughter identified with the school, supporting her son's difficult decision to stop playing hockey because not harming his friends was more important to him than staying on track to being a very successful hockey player, and making extra money to support her eldest daughter's desire to go to a summer band camp. Through the process of talking with, and listening to, her children as they worked through problems together, Shar discovered that she understood her children more easily and deeply and that they, in turn, took responsibility for themselves and their actions.

Shar values each child for their uniqueness and, as a result, listens to all children when they tell her about what is going on in their lives. Shar continues to pay attention to what children believe their needs are by listening to what they have to say. Here she describes how she strives to develop human relationships that are based on honesty, respect and love: 


\begin{abstract}
My daycare children are absolutely aware that they are loved. That's something that I'm able to hold right there all the time. Listening to them is constant. Even when I'm at my worst moment in the daycare, the child speaks and I hear what they say. And if I don't have time to answer them immediately, I'll say, "(child's name), I heard what you said. Can you wait just a second, 'cause right now I'm doing this other thing and I can't really pay attention. But I know, I heard you and I will pay attention in just a minute. '
\end{abstract}

I'm trying to acknowledge that they are real. So much of what goes on in the culture is denial of the reality of their being. It's a wanting to pretend they're not really there, so we don't have to acknowledge their life. So, we sit at lunchtime and the kids will be talking about something and they ask me lots and lots of things that are incredibly personal.

Informed by her feminism and by her life experiences and knowledge, Shar consciously engages with children in caring and loving ways she believes foster their self-esteem and their sense of self-worth. She speculates that the children who interact with her learn that when they speak, they can expect to be heard and that their concerns are relevant. Shar has seen many of the children she has cared for develop a sense of themselves as people who have a voice that is worthy of being listened to. She believes that they have successfully learned to be subjects in the world, who are accountable for their own actions and are able to hold others accountable for their's.

Tammy, a thirty-seven-year old, single mother of a son and daughter under the age of ten, acknowledges that mothering is a huge responsibility and should not be taken lightly because "our society is going to come out of what we teach these children now." Tammy views her connection with her children as more profound than her connection with others, including her co-workers at a socialist magazine where she works on socialist politics for six to seven hours a day.

Being aware of the huge responsibility and the significant impact she has as a mother on the lives of her children, Tammy consciously teaches them about equality, respect and justice. She tells me that because she believes children "have a lot of power, particularly in their decision making" she encourages them to "think for themselves while trying not to be too interventionist." Tammy shared her response of a recent incident with me to illustrate how she encourages and supports her children to be true to their own values, even when their values may conflict with her own or with those of people in positions of authority. Tammy reminds her children about making choices and the responsibility that accompanies their actions when she explains her thinking to them about a new school program of instituting "pink slips" to students for inappropriate behaviour and "late slips" for being late: 


\begin{abstract}
What really matters is what you were doing, whether it really was appropriate or inappropriate, not how the teacher saw it or how the principle saw it. If you knew what you were doing was for a logical reason, and it was working towards a constructive end, I don't mind if you get a "pink slip". It's a piece of pink paper, who cares?
\end{abstract}

What is crucial to Tammy, Shar, and the other feminist mothers in this group, is that children learn to be critical thinkers who are able to analyse various situations and make decisions for themselves based on their own experiences, knowledge and reasoning. By not minimizing, but rather by fostering the agency of their children in their relationships with them, they nurture their children to grow and develop as subjects in their own right. In their ongoing interactions with their children, they encourage them to decide for themselves what they think and why, and how they view and want to live in the world.

\title{
The Transformative Work of Feminist Mothering
}

Mothering with a feminist consciousness has enabled these women to break free from the restrictive elements of the institution of motherhood and to re-shape their mothering. They are empowered to exercise their self-governance and to mother in ways that are harmonious with their own feminist analysis and re-framing of motherhood, including: valuing relationships based on respect, refusing to engage in interpersonal affiliations that are oppressive and, whenever possible, encouraging their children to make decisions and be responsible for themselves. Thus, they provide alternative mothering models for themselves, their children and others.

Francis, the 45 year-old lone mother of a nine year-old son, shares an experience she had with her son to demonstrate how her feminist mothering has assisted in her son's ability to think critically about the world and share his analysis with others:

\begin{abstract}
I'll tell you a story, it was just yesterday, it was so validating. My child and I were presenting Hanukkah to the class at school. I started to talk to the kids about how, you know, Hanukkah talks about the Maccabees and the soldiers and the men and the generals, but most of the history forgets about the women's contributions. My kid yelled out, "Ya! There's HERstory!" And I thought that was just perfect. My kid's got a HERstory, and he loved this notion. History. HIS story. HER story. So, I'm sure it's the first time the class has heard the notion of HERstory and he presented it! It was just great.
\end{abstract}

By offering her son an alternative and more inclusive understanding of his own heritage than is commonly presented, Francis believes she increases her son's understanding that 
there are experiences and realties not presented in the everyday realm of knowledge. She also encourages him to share alternative knowledge and history with other people. Francis views her son's strong presence and participation in sharing women in the herstory of Hanukah with his grade four classmates as testimony to her feminist mothering and as an example of how her feminist mothering may extend beyond her son, his home and family, to the world where he is - be this with friends, in school, at work, or in society at large.

\section{Conclusion}

Each of the mothers I spoke with believe that their mothering contributes to social change because, as Francis notes, they are not "conditioned mothers" who are going to perpetuate "standard values" in their children of how mothers, families and boys and girls should be. Rather, informed by their feminism, they provide their children with feminist influenced alternatives to the dominant assumptions and expectations of gender, mothering and families.

Using their feminist understanding(s) and analysis of the world, these particular mothers craft space for themselves within the institution of motherhood to resist and challenge patriarchal expectations of them as mothers and to generate new ways of parenting for themselves. Within their vision and practice of feminist mothering, these women consciously create room for their children to develop their own thinking and to share their knowledge and thoughts about themselves and the world around them. This particular group of feminist mothers acknowledge children as actors who can use their skills of questioning the standard view of the world to both discuss other ways of thinking and influence their own social networks through their relationships with others. By practising self-governance in their mothering and fostering autonomy and critical thinking in their children, they encourage their children to speak their own minds and to discuss ideas that, at times, may conflict with those of their mother's and other's. The result, according to these mothers, is that their children, who are often otherwise silenced, learn that they are powerful people who can think for themselves and articulate their needs.

Through the conscious act of feminist mothering, these women, together, with their children, are transforming the institution of motherhood, their mother/ child relationships and, to a limited degree, the larger world through their interpersonal relationships with others. 


\section{REFERENCES}

Baker, C. 2004. "Telling our Stories: Feminist Mothers and Daughters." In Mother Outlaw: Theories and Practices of Empowered Mothering. Andrea O'Reilly (ed.). Toronto: Women's Press, pp. 95-104.

Buchanan, A.J. 2003. Mother Shock: Loving Every (Other) Minute of It. WA: Seal Press.

Buskens, P. 2004. "From Perfect Housewife to Fishnet Stockings and Not Quite Back Again: One Mother's Story of Leaving Home. In Mother Outlaws: Theories and Practices of Empowered Mothering. Andrea O'Reilly (ed.). Toronto: Women's Press, pp. 105-119. Center for History and New Media. 2004. http://chnm.gmu.edu/features/sidelights/crocker.html. Accessed $16 / 01 / 2005$

Chodorow, N. 1978. The Reproduction of Mothering: Psychoanalysis and the Sociology of Gender. Berkeley: University of California Press.

Dally, A. 1982. Inventing Motherhood: The Consequences of an Ideal. London: Burnett Books.

de Marneffe, D. 2004. Maternal Desire: On Children, Love and Inner Life. Little, Brown.

Douglas, S. \& M. Michaels. 2004. The Mommy Myth: The Idealization of Motherhood and How it has Undermined Women. New Jersey: Free Press.

Fox. F. 2004. Dispatches from a Not-So-Perfect Life, or How I Learned to Love the House, the Man and Child. New York: Harmony Books.

Green, F. 2004a. "Feminist Mothers: Successfully Negotiating the Tension Between Motherhood as 'Institution' and 'Experience'." In Mother Outlaws: Theories and Practices of Empowered Mothering. Andrea O'Reilly (ed.). Toronto: Women's Press, pp. 31-42.

Green, F. 2004b. "Feminist Mothers: Successfully Negotiating the Tension Between Motherhood as 'Institution' and 'Experience'." In From Motherhood to Mothering. The Legacy of Adrienne Rich's Of Woman Born. Andrea O’Reilly (ed.). New York: SUNY Press, pp. 125-136.

Green, F. 2001. Living Feminism: Pedagogy and Praxis in Mothering. Unpublished PhD dissertation. University of Manitoba.

Gordon, T. 1994. Feminist Mothers. New York: New York University Press.

Halliday, A. 2002. The Big Rumpus: A Mother's Take from the Trenches. WA: Seal Press.

Hanauer, C. 2003. The Bitch in the House: 26 Women Tell the Truth About Sex, Solitude, Work, Motherhood and Marriage. Perennial Currents.

Hayes, S. 1996. The Cultural Contradictions of Motherhood. New Haven: Yale University Press.

Horwitz, E. 2004. "Resistance as a Site of Empowerment: The Journey Away from Maternal Sacrifice." In Mother Outlaw: Theories and Practices of Empowered Mothering. Andrea O'Reilly (ed.). Toronto: Women's Press, pp. 43-58.

Margulis, J. 2003. Toddlers: Real-life Stories of Those Fickle, Irrational, Urgent, Tiny People We Love. Publishers Group West. 
McCullough, K. 2004. "Of Women (but not Man or the Nuclear Family) Born: Motherhood Outside Institutionalized Heterosexuality." In From Motherhood to Mothering: The Legacy of Adrienne Rich's Of Woman Born. Andrea O'Reilly (ed.). New York: SUNY Press, pp. 103-124.

O'Reilly, A. 2004. "We were Conspirators, Outlaws from the Institution of Motherhood": Mothering against Motherhood and the Possibility of Empowered Maternity for Mothers and their Children." In Mother Outlaw: Theories and Practices of Empowered Mothering. Andrea O'Reilly (ed.). Toronto: Women's Press, pp. 95-104.

Reddy, M.T., Roth, M. \& A. Sheldon (eds.). (1994). Mother Journeys: Feminists Write about Mothering. Minneapolis: Spinsters Ink.

Rich, A. 1986. Of Woman Born: Motherhood as Experience and Institution. London: Virago.

Ruddick, S. 1989. Maternal Thinking. Towards a Politics of Peace. Boston: Beacon Press.

Ruddick, S. 1984. "Maternal Thinking.” In Mothering: Essays in Feminist Theory. J. Trebilcot (ed.). New Jersey: Rowman \& Allanhead, pp. 213-230. 